\title{
The Changing Dynamics of Gender in the Labour Market: A Jamaican Perspective
}

\author{
Ian Boxill* and Deborah Fletcher
}

The University of the West Indies, Mona, Jamaica

\begin{abstract}
One of the barriers to human development is gender inequality. In many parts of the world there is a large concentration of females in non-technical service jobs, while their male counterparts are employed in more high skilled technical jobs which are associated with greater prestige and higher levels of remuneration. Nevertheless, the evidence points to a change in how gender roles are being perceived intergenerationally, at least in the case of Jamaica. Drawing on the findings from two studies (1997 and 2017) of lower and lower-middle income communities in Jamaica, along with a review of official statistics on the labour market, this paper discusses the extent to which perceptions of gender roles have remained stereotypical in regard to the household and the workplace. The paper concludes that while gender stereotypes persists the situation has been changing and gender roles are no longer seen as natural or immutable.
\end{abstract}

Keywords: Gender roles, patriarchy, inequality

\section{Introduction}

Gender inequality is a major barrier to human development in the twenty-first century. The study of gender explores differences in the experiences of the sexes in all societies. An examination of gender related issues provides a lens through which one can explore how power structures, norms and values impact opportunities of men and women within a society.

In the Caribbean, colonialism bequeathed highly stratified societies and systems of social relations between men and women that were based on a patriarchal ideology. This, despite the fact that the system of slavery gave no explicit place to the patriarchal family, since men and women worked alongside each other in the agricultural fields performing some of the most strenuous tasks imaginable. Despite the many positive changes in gender relations that have occurred in the Caribbean since the 1960s, the period during which decolonisation began, what obtains is an imbalance in power relations between men and women. This is particularly true in the workplace where jobs in technical areas are often considered as being "masculine". In addition, non-technical jobs are seen as being more "feminine" and as such are usually female dominated. To get a better understanding of the nature of gender segregation in the Jamaican labour market and the extent of gender stereotyping, this paper attempts to answer the following questions:

1.Have changes in the Jamaican labour market been favourable to women?

2.Is there evidence of sex segregation in the wider Jamaican labour market?

3.Is there still evidence of gender stereotyping?

4.Have expectations changed as it relates to male/female participation in technical and non-technical jobs?

\section{Literature Review}

It has been argued that the patriarchal nature of Caribbean societies has its genesis in the colonization of the region. In addition, many Caribbean social scientists are of the view that the patriarchal system lies at the foundation of modern capitalism (Hart, 1989). It has been argued that with some variations the system provides 
a context in which men are able to restrict women's access to the labour market. The result is that women are often "directed" to low paying jobs and forced to adhere to the principles of the domestic division of labour (Witz, 1992); while this is happening women's bargaining position in the labour market is weakened.

Some gender scholars are of the view that patriarchy sometimes manifests itself in male domination of critical sectors of the economy with women playing subordinate roles (Hardwick, 1998; Brown-Campbell, 1998). Additionally, an emerging school of thought exist which contends that relations in the family are similar to those in the formal labour market. That is, within families males continue to lead even in instances where the family structure is matrifocal in nature. This makes it difficult to overlook the link between capitalism and patriarchal systems in both the family setting and the workplace. Especially in light of the fact that signs of patriarchy persist within the Caribbean where women continue to maintain labour participation rates comparable to those of their North American counterparts (Mohammed, 2002).

\section{Gender segregation in the workplace}

In general, Caribbean gender scholars argue that women have always worked outside the home environment; however, their participation in the more technical sectors of the economy have been significantly lower than that of their male counterparts (Hart, 1989). Ricketts; for example, points out that between 1993 and 2000 Jamaican males dominated areas such as skilled Agricultural and Fishery Workers, Craft and Trades Workers; Plant and Machine Operators and Assemblers and Elementary Occupations. On the other hand, female participation in industries such as Plant Machine Operators and Assemblers declined significantly. Numerically, female participation in categories such as Plant and Machine Operators and Assemblers, fell from $37.6 \%$ in 1993 to $15.1 \%$ in 2000 (Bailey, 2003, p. 64). These changes suggest that though women continue to maintain a presence in the labour market their dominance is in the service sector.

\section{Changing of the guard}

Increasingly, men and women are challenging conventionally held attitudes and assumptions concerning male and female work. A quick analysis of the labour market data reveals that women have been moving into traditional male dominated areas of work. Additionally, several researchers have noted that characteristics such as empathy and consensus building which are traditionally associated with women are more valuable to business than the more competitive "masculine" model or the brawny "masculine" strength which is often considered as a useful stimulus for the blue-collar manufacturing environment (McGinley, 2013).

Today more men are attracted to female-dominated occupations and more females are encouraged to take up jobs in male-dominated fields -- particularly the technical ones (Bettio \& Verashchagina, 2009). The fact that men and women are willing to venture into industries that were previously stereotyped suggest that the labour market is slowly being desegregated. This desegregation of the labour market in Jamaica allows policy makers and employers to alleviate skill and labour shortages as well as it will allow more individuals with appropriate skillset to work in areas dominated by the other sex.

Despite these critical changes the extent to which Caribbean countries, such as Jamaica, are able to make economic progress will be dependent on the speed with which the institutionalized forms of gender discrimination are removed. For countries of the region to advance women who join the labour force should be able to effectively use their intellect and skills to impact policy and decision-making processes. The rapid development of knowledge economies is another game changer in the gender discourse. Knowledge is now seen as a major driver of industry, productivity and economic growth. In a knowledge based economy males and females are encouraged to tap into their creativity and embrace technology rather than rely on brawn. With increased use of technology in the home and work environment the need to rely on powerful physique has become less important for work. Instead, the hype and swag associated with being physically fit has traded place with robots and more service-oriented jobs. This change has resulted in increased female participation in the labour market while propelling economic growth and development of many countries. 


\section{Methodology}

A mixed methods approach was used to gather data, allowing the researcher to gain breadth and depth of issues while facilitating corroboration. Data collection began with participant observation of individuals enrolled in the University of the West Indies Community Film Project. This was followed by a review of secondary data. The secondary data sources used include the Jamaica Labour Force Survey 1990-2015, The World Bank Labour Force Database and The World Economic Forum Report. Semi-structured video interviews were also conducted, and a survey administered within 10 inner-city communities across Jamaica. These inner-city communities were chosen to match those in the Boxill (1997) study.

Information gathered from the review of secondary data together with information from the semi-structured interviews was used to guide the development of the survey instrument which consisted of both open and closed ended questions. A total of 450 questionnaires were administered to 202 Males and 227 Females ages 16-35 years.

\section{Findings}

i. Have changes in the Jamaican labour market been favourable to women?

Jamaica witnessed a minor change in its male/female labour force participation rate between 1990 and 2015 , with rates relatively stable at $78.1 \%$ for males in 1990 to $77.2 \%$ in 2015; among females the rates fell slightly from $59.5 \%$ in 1990 to $56.7 \%$ in 2015(World Bank, 2018). Two major factors affecting labour force participation rates are: employment opportunities and the demand for income. A 2003 report by the International Labour Office (ILO) shows that labour force participation rates tend to be higher as employment opportunities grow for both men and women (International Labour Office, 2003). Based on the data it is difficult to say that changes in the labour market have favoured females. Instead, one can argue that females' continued presence in the work environment can be attributed to factors such as declining fertility rates (in 1990 fertility rates stood at $2.99 \%$ by 2015 the fertility rates fell to $2.04 \%$ ) and increased educational and training opportunities. Given that Jamaican women are having fewer children they are spending less time in the home caring for their infant and new born children. In addition, female enrolment in tertiary and secondary level institutions remains higher than for males. Even though the Jamaican woman maintains a continued presence in the labour market the reality is that being able to access a job does not translate into an automatic escape from poverty and social deprivation. This is because a large percentage of females participating in the labour market are employed in low waged jobs which puts them at risk of slipping into and out of poverty.

ii.Is there evidence of sex segregation in the wider Jamaican labour market?

In the paper we use the variables of 'income' and 'occupational groups' to determine whether there is occupational sex segregation in the Jamaican labour market. When we examine the income earning gap between males and females in Jamaica it is clear that males continue to earn more than their female counterparts. In 2006 Jamaican men earned on average annually US\$1,665 more than their female counterparts (World Economic Forum, 2006). By 2015 they were earning USD\$ 4,366 more than their female counterparts (World Economic Forum, 2015). This wage gap can be explained by the fact that a number of women work in lowerpaid and lower-skilled jobs or in the informal sector where income often fluctuates. In addition, women are also known to take more time off from work to care for an ailing child or an elderly family member. It is said that the gender pay gap continues to widen worldwide where women have been earning $57 \%$ of what men earn (Gillett, 2018). This significant gap is in large part a function of gender discrimination in the workplace.

In the Jamaican labour market men and women tend to be concentrated in different sectors. A close examination of the 2010 and 2015 data shows the low concentration of males in the Education and Private Households with Employed Persons Industries sector. Notwithstanding this, they were making strides in the 
goods producing industry in the areas of Skilled Agricultural, Hunting, Forestry and Fishery and Construction. Based on the ILO International Standard Industrial Classification, filmmaking falls under the Information and Communication Industry; however, in the Jamaican Classification, Transport and Storage is linked with Communication. Close examination of the Jamaican data shows that the Transport, Storage and Communication Industry is male dominated.

This segregation of the labour market is also reflected at the micro level. In this paper we draw on a case study of a project in the creative industries to see if this segregation is reflected - the University of the West Indies Community Film Project (UWICFP). The UWICFP is an outreach project of the Centre for Tourism and Policy Research, at the University of the West Indies, Mona Campus, which encourages at risk youth from innercity/urban communities across Jamaica to get directly involved with innovative storytelling and filmmaking around important community and national issues. It trains participants in filmmaking over a three-month period. As part of the training, participants are required to choose areas of concentration. Note that the project trains participants in a number of specialisations, such as editing, production, make-up and cinematography. A look at the data show that during the practical segment of the course, the more technical areas such as editing and cinematography were dominated by males whereas the non-technical areas such as production and makeup were dominated by females. A breakdown of the male/female participation over the five year period reveals that of the 140 males and 60 female participants: five (5) females chose to work in editing while more than 40 males opted for this area of concentration. Less than 10 females gravitated towards cinematography compared to almost 50 males, with the majority of females (45) choosing to work in production.

These trends indicate that the male participants gravitated towards jobs that were more hands on while their female counterparts were more interested in organizing tasks. Researchers, such as Culbertson (1994), who have analysed similar trends explain that, traditionally, men were likely to choose to work in technical areas given that that sector was critical in shaping their identity as "masculine". However, the era is fast coming to an end where men tend to use their job titles, such as construction worker, as an identifier; that is, as sign posts of masculinity. (Culbertson, 1994).

Another possible reason for the concentration of men and women in different jobs is men are more inclined to technical areas given that non-technical jobs are considered uninteresting. Furthermore, jobs dominated by women are perceived as requiring:

“low intelligence;' necessitating that the holder has a high tolerance for boredom” (Williams, 1995; p.2).

Drawing on the work of conventional theorists one can argue that women were most likely to choose nontechnical jobs because they were socialized to be passive and less ambitious relative to men. Ambition and aggression are characteristic honed by men which allow them to compete successfully in the labour market. Linked to this, there are those who contend that technical areas of the labour market are buffered by a 'glass ceiling' which favours the advancement of men over the progression of women. A 2017 KPMG study, for instance, shows that there is a perception that glass ceilings for women exist in industries such as finance, retail, banking and consultancy. This situation in a context "where there are an equal number of male and female employees filling entry and middle level manager roles" (p. 25).

Taylor, et al., (2012) also state that in industries such as engineering men are seen as members of the in-group and as such are treated more favourably than females in terms of the amount of remuneration they earn for work, as well as in their career advancement. Women, on the other hand, are seen as part of the out-group and are generally treated less favourably than men. Based on our review of the labour market data, along with the case study, we conclude that despite the dynamism within the labour market there is the persistence of occupational sex segregation in Jamaica.

iii.Is there still evidence of gender role stereotyping? 
Regarding the issue of gender stereotyping we looked at two studies to determine evidence of gender stereotyping. The first (Boxill, 1997) which was completed in 1997 examined the extent to which perceptions of gender roles were rigid or flexible and the second (Boxill et al 2017) is a replication of the first. In general, the findings of the 2017 study do not reveal much evidence of strong gender role perceptions among those interviewed. However, there does appear to be the persistence of female roles in the household in regard to shopping, preparing meals and childrearing (of girls). Note though that this perception is not as strong as in 1997. In the 1997 study more than half of the respondents suggested that females should maintain the responsibility of shopping $(62.2 \%)$ and preparing meals $(51.8 \%)$ in the home (see table). Close examination of the findings in the table reveals that males were more likely to identify these two areas as female roles. Fast forwarding to 2017 and less than half of the respondents believe that females should maintain the responsibility of shopping (44.4\%) and preparing meals (35.5\%). Although the results for both surveys are not significantly different, unlike in 1997, the 2017 survey results show men as being less likely to associate either roles as being predominantly female roles.

Perceptions of gender roles and responsibilities in permanent relationships

\begin{tabular}{|c|c|c|c|c|c|c|}
\hline \multirow{2}{*}{ Domestic activities } & \multicolumn{3}{|c|}{1997} & \multicolumn{3}{|c|}{2017} \\
\hline & Man & Woman & Both & Man & Woman & Both \\
\hline Earning money for the household & 24.5 & 1.5 & 74.0 & 13.5 & 1.2 & 85.3 \\
\hline Doing the shopping & 3.3 & 62.2 & 34.4 & 2.5 & 44.8 & 52.8 \\
\hline Paying the bills & 40.5 & 6.9 & 52.6 & 20.9 & 6.4 & 72.4 \\
\hline Choosing a school for the children & 5.4 & 22.4 & 71.9 & 3.4 & 18.4 & 78.2 \\
\hline Seeing that the children go to school & 5.9 & 16.8 & 77.3 & 6.2 & 16.9 & 76.9 \\
\hline Taking the children to church & 1.3 & 23.2 & 75.5 & 3.7 & 21.8 & 74.5 \\
\hline Preparing the meals & 1.8 & 51.8 & 46.4 & 3.1 & 37.5 & 59.4 \\
\hline Entertaining friends & 7.2 & 16.4 & 76.2 & 15.5 & 12.7 & 71.4 \\
\hline Teaching boys about sex/ relationships & 28.3 & 12.5 & 59.2 & 39.0 & 4.9 & 56.1 \\
\hline Teaching girls about sex/relationships & 5.6 & 41.6 & 52.6 & 4.9 & 46.9 & 48.2 \\
\hline Deciding when children should be at home at nights & 7.4 & 11.5 & 80.6 & 9.2 & 9.8 & 81.0 \\
\hline Deciding how many children to have in a family & 6.4 & 10.2 & 83.4 & 6.1 & 16.3 & 77.3 \\
\hline
\end{tabular}


In regard to perceptions related to the labour market a little less than a third (29\%) of the respondents were of the view that there are designated male and female work roles. With respect to the occupational groupings that featured prominently in the male/female work dichotomy, construction and carpentry were identified as men's work while domestic helper, office worker and hairdressers featured prominently among the women's work. Given that less than half of the respondents shared this perception of male and female work, it may be concluded that at least in regard to perceptions, gender role stereotypes are slowly disappearing from the Jamaica labour market (see pie chart).

Is there such a thing as male/female work?

In their views on the labour market respondents stated that although more men were entering traditional female occupations, such as nursing, they still struggle against the stereotypes of what a nurse looks like. Similarly, respondents were of the view that though more women were entering the construction industry, the way in which the industry was being portrayed made it unattractive for females. Agapiou (2002) (in Abidemi, et al., 2015) contend that:

"The predominant image of construction is that of a male-dominated industry requiring brute strength and a good tolerance for outdoor conditions, inclement weather and bad language" (p.4).

These stereotypes are among the factors that have prevented both males and females from working in jobs that are not seen to be associated with their gender, thus underscoring the supporting ideology that reinforces notions of what it means to be a male or female.

iv. Have expectations changed in regard to male/female participation in technical and non-technical jobs?

In relation to gendered jobs, the 2017 survey results show that the majority of the respondents believe that there is no such thing as male and female work in the home (81.6\%) and in the workplace $(77.7 \%)$. Those who were of the view that there was such a thing as "male work" or "female work" in the workplace identified largely technical jobs as "men's work", while more caregiving type jobs were viewed as examples of "women's work". Some of the technical jobs associated with "men's work" in the home included lifting heavy objects, fixing the electrical lights, moving furniture and working on the outside of the house. Technical "men's work" in the workplace also included lifting heavy objects. One type of non-technical "female work" identified in the home was washing the bathroom. In the workplace non-technical "women's work" entailed desk-work and customer care.

Theorising perceived gender roles

Given that countries within the Caribbean have different historical experiences compared to North American and European countries, Caribbean scholars use slightly different approaches in theorizing gender roles. In fact, Caribbean scholars continue to criticize what they call "the westocentric" analyses of gender and work of postmodernists' writers (Slocum \& Shields, 2008, p.696). Scholars within the region are of the view that one must take into consideration the history of colonialism, class and race relations when looking at matters relating to gender equality. For instance, Safa (1986) explains that in lower class communities' males appear to be less dominant when compared with men of other classes. She contends that within these communities women have greater levels of economic autonomy and are not as dependent on men as women in higher social classes. Women of these communities appear to be somehow more empowered to the extent where they share responsibility for the household. This is not to gainsay the absence of gender inequality in the Caribbean. Quite the contrary. A study of Sexual attitudes and practices of males in Barbados by Dann (1987) revealed that many men described women as weak and needing to be controlled by men. In addition they were of the view that women should be largely confined to the household to serve their male partners.

This acknowledgement shows that many of the respondents still subscribe to the traditional idea of gender role which reinforces gender inequality. However, as the data from the two Jamaican studies show, these 
stereotypical views of gender roles have changed considerable since the 1980s. But that is the case of Jamaica. It would be interesting to find out what obtains in the neighbouring Caribbean and Latin American countries, as well as what the results of a follow-up study in Barbados would yield in regard to these issues.

\section{Conclusion}

Given the small sample size of the survey, results do not necessarily represent the entire Jamaican population. Nonetheless, we can conclude from our findings that while gender role stereotyping persists in Jamaica it is slowly changing. That is, notions of rigid male and female roles at work or in the home appear to be a feature of the past.

The concentration of females in non-technical jobs in the wider society or at the micro level, such as in the UWICFP, is clearly not a natural occurrence and appears to be changing, albeit slowly. In countries, such as Jamaica, where gender role stereotyping persists there is the inevitability of the stagnation of social and economic progress. This implies that addressing gender equality, in all of its manifestations, is a precondition for ensuring human freedom and fostering development.

\section{References}

Abidemi, A. M., Dilanthi \& Ayobami, M. M., 2015. Gender barrier in construction industry: A review of women involvement. International Journal of Modern Management Sciences, 4(1), pp. 1-10.

Bailey, B. \& Ricketts, H., 2003. Gender vulnerabilities in Caribbean labour markets and decent work provisions. Social and Economic Studies 52:4, pp. 49-81.

Bettio, F. \& Verashchagina, A., 2009. Gender segregation in the labour market: Root causes, implications and Policy responses in the EU. Belgium: European Commission.

Boxill, I., 1997. Perceptions of gender roles in urban Jamaica. Humanity and Society, 21(2), pp. 182-189.

Boxill, I., Fletcher, D. \& Segree, M., 2018. The dynamics of gender and development in a changing society. Kingston: CTPR, UWI, Mona Working paper.

Brown-Campbell, G., 1998. Patriarchy in the Jamaica Constabulary Force: its impact on gender equality. Kingston: Canoe Press.

Culbertson, P. L., 1994. Counselling Men. Minneapolis: Fortress Press.

Dann, G., 1987. The Barbadian Male: Sexual attitudes and practices. London: Macmillan Caribbean.

Gillett, R., 2018. Equal pay for equal work is not the way to close the gender pay gap. Business Insider, 10 April.

Hardwick, J., 1998. Practice of Patriarchy: Gender and the Politics of Household authority in early modern France. Pennsylvania: Penn State University Press.

Hart, K., 1989. Women and the sexual division of labour in the Caribbean. Mona, Kingston, Consortium Graduate School of Social Sciences.

International Labour Office, 2003. Key indicators of the labour market. 3rd ed. Geneva: International Labour Organization.

KPMG, 2017. Kilidi Kirmak: Breaking the glass ceiling. [Online] Available at: http://www.kpmg.com.tr [Accessed 4 June 2018].

McGinley, A. C., 2013. Masculinity, labour and sexual power. Boston University Law Review, Volume 93, pp. 795-813.

Mohammed, P., ed., 2002. Gendered realities: essays in Caribbean feminist thought. Kingston: The University of the West Indies Press.

Safa, H. I., 1986. Economic Autonomy and Sexual Equality in Caribbean Society. Social and Economic Studies, 35(3), pp. 1-21. 
Slocum, K. \& Shields, T. L., 2008. Critical explorations of gender and the Caribbean taking it into the twentyfirst century. Identities, pp. 687-702.

Taylor, A., James, K. \& Adam, M., 2012. Leveraging workforce diversity using a multidimensional approach. In: C. Scott \& M. Byrd, eds. Handbook of research on workforce diversity in global society: Technologies and concepts. PA, USA: IGI Global, pp. 203-224.

Williams, C., 1995. Still a man's world: men who do women's work. California: University of California Press.

Witz, A., 1992. Professions of Patriarchy. New York: Rutledge.

World Bank, 2018. Labour force participation. [Online] Available at: https://data.worldbank.org [Accessed 20 April 2018].

World Economic Forum, 2006. The Global Gender Gap Report, Geneva, Switzerland: World Economic Forum. World Economic Forum, 2015. The Global Gender Gap Report, Geneva, Switzerland: World Economic Forum.

World Economic Forum, 2017. These 5 charts show how big the pay gap is between men and women. [Online] Available at: https://www.weforum.org/ [Accessed 18 May 2018].

The UWI Community film project was started in 2011 by a professor at the university. The aim of the project is to train at-risk youths in the rudiments of film making. Since its inception, the project has expanded to over 32 communities in the cities of Kingston and Montego Bay, graduating over 200 persons in filmmaking. 